\title{
A Doctor Facing Turbulent Times: Antoni Tomasz Jurasz, Citizen of the World
}

\author{
Anita Magowska
}

Published online: 4 June 2011

(C) The Author(s) 2011. This article is published with open access at Springerlink.com

\begin{abstract}
The eponymous of the Jurasz procedure is Antoni Tomasz Jurasz (1882-1961). The procedure is a standard approach to treating mature pancreatic pseudocysts that are in contact with the stomach, although recent advances in instrumentation have empowered surgeons to perform pseudocystogastrostomy laparoscopically for this problem. Dr. Jurasz was born in Germany but felt himself as Polish as his ancestors. He graduated from Heidelberg with a degree in medicine. Over the following years, he developed a German surgery school, especially helping with the achievements of Erich Lexer and Erwin Payr. During the period between World Wars I and II, Jurasz chaired and led the Surgery Clinic of Poznan University in Poland; and he gave lectures and performed public operations abroad. These activities, together with articles published in German-, French-, and English-language medical journals, made him a world-renowned figure in the field of abdominal and thyroid surgery. During World War II, he revealed exceptional traits, taking part in the September Campaign in Poland as a surgeon. He then organized the Polish School of Medicine and the Paderewski Hospital in Edinburgh. Despite his outstanding mind, generosity, and merits, A. T. Jurasz became persona non grata in Communist Poland, which ultimately persuaded him to emigrate to the United States.
\end{abstract}

\footnotetext{
A. Magowska $(\square)$

Department of History of Medical Sciences,

Poznan University of Medical Sciences,

ul. Przybyszewskiego 37A, 60-356 Poznan, Poland

e-mail: anitamagowska@yahoo.com
}

\section{Introduction}

During the first half of the 20th century, two world wars and political turmoil not only represented a watershed in history but also in doctors' lives. One of these professionals was Antoni Tomasz Jurasz. Originally a professor of surgery in Germany, owing to the turbulent times he successively became a professor of surgery in Poland, a war hero, the dean of a school of medicine in exile, an unofficial wartime ambassador of Poland, and finally an émigré to the United States. This is the story of how political changes can hamper the development of medicine and incapacitate a prominent surgeon.

\section{In Germany}

Antoni Tomasz Jurasz was born on February 11, 1882 in Heidelberg, the son of a Polish emigrant (Poland had been annexed by Austria, Prussia, and Russia, so Polish doctors did not find career opportunities in their homeland.) His father, Antoni Stanislaw Jurasz (1847-1923), was a professor of ear, nose, and throat diseases; and his mother was an Englishwoman, Caroline, from the Gaspey family. At the family home, Antoni Jurasz Jr. took an interest in medicine, learned to have a deep affection for Poland, and developed fluency in several languages - characteristics and skills that shaped his lifetime. In 1906, he graduated in medicine from the University of Heidelberg. He next completed internships on the surgical ward of the German Hospital in London and at the Internal Medicine Clinic in Heidelberg [1], led by Ludolf von Krehl (1861-1937), a pathophysiologist known for his interest in psychosomatic illness [2].

He took his doctorate in 1907 , with his thesis on tumor changes in the connective tissue of the pelvis. Typically for 
doctors at that time, he gained knowledge and professional experience working as an unpaid assistant at the Department of Pathological Anatomy of Heidelberg University during 1907 and as a doctor for the German merchant navy (which allowed him to learn about tropical diseases in Africa and India) for part of 1908. After returning to Europe, he held a position of surgeon at the German Hospital in London. In 1909, he worked under Erich Lexer (1867-1946), a pioneer of plastic surgery, at the surgical clinic in Königsberg. During the years 1911-1915, he was an assistant to Erwin Payr (1871-1946) at the surgical clinic in Leipzig. Payr was the first surgeon to use ozone treatments to control and kill bacteria, [1]. During a period of cooperation with Lexer and Payr, Jurasz produced several publications, proving that his interests focused more and more on the complications of anesthesia [3] and abdominal surgical problems [4].

During the first Balkan War (1912-1913), he participated in the expedition of the German Red Cross to Constantinople. After returning to Leipzig, he was asked to give some lectures on fractures and dressings. Two years later, he was appointed Chief Physician of the surgical ward and Managing Director of the Hospital of the Holy Mary in Frankfurt am Main. His promotion to the rank of professor in 1919 foreshadowed an impressive academic career in Germany [1].

\section{In Poland}

At the time, Poland was an independent and sovereign state, although struggling with the backwardness that had remained after the Period of Partition and visible in many public spheres, including higher education and medical care. Some new universities were established, and the authorities of one of them, Poznan University, invited Jurasz to organize and be in charge of a surgical clinic. He accepted the proposal and in September 1920 he went to Poznan (Posen) [1]. Straightaway, it turned out that the City Hospital, planned as the seat of the surgical clinic, lacked adequate rooms. Acting with all his energy, Jurasz moved the clinic to the Hospital of the Sisters of Mercy and then had the building thoroughly changed according to his instructions (Fig. 1). He arranged his clinic in accordance with German standards of surgery, equipping the hospital with specialized clinical laboratories, rooms for performing autopsies and for experimental procedures on animals, an animal house, demonstration operating room, lecture hall, modern operating ward, radiography laboratory, rehabilitation facility for patients after bone and joint injuries, a museum, an archive, and a library with a reading room [5]. From his frequent scientific trips abroad, he brought instruments and medicines, which he purchased with his

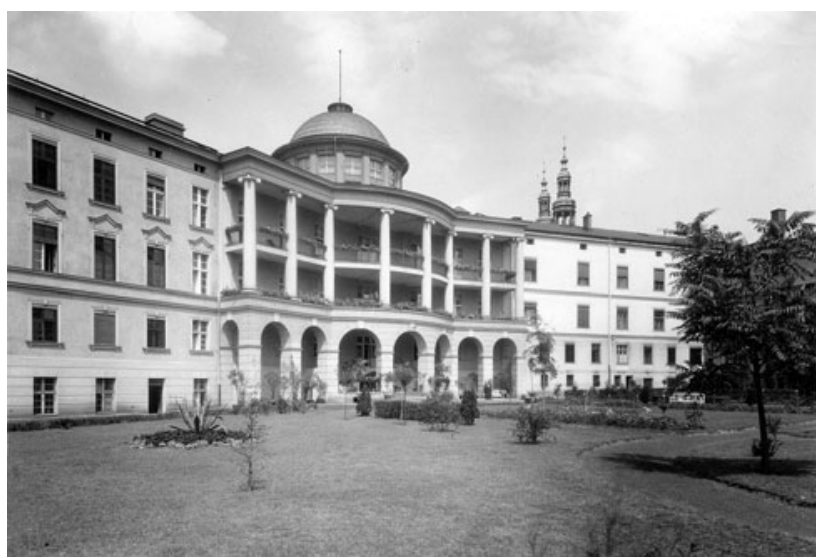

Fig. 1 Hospital of the Sisters of Mercy in Poznan during the period between World Wars I and II. From Halas [5]

own money to improve therapy. In 1931, he organized a radiotherapy section in the clinic, the first in Poland, patterned on the Stanford Cade Institute of Westminster Hospital in London. Thus, a modern surgical clinic was created that was one of the best in Poland [6].

The period of his work in Poznan was the most creative in Jurasz's life. About 20 publications in German, English, French, and Polish medical journals proved his expert knowledge of thyroid surgery [7]. He also described a reconstructive operation of the bladder $[8,9]$, an approach to a pancreatic cyst through a transverse incision in the anterior gastric wall [10-13], a movable kidney [14], bile ducts [15, 16], and stomach [17]. His most significant contribution to the surgery was published in 1931: a method for internally draining a pancreatic pseudocyst through the gastric wall that was so firmly fused with the cyst that no sutures were needed [10]. Transgastric pseudocystogastrostomy, known as the Jurasz procedure, became the standard treatment for mature pancreatic pseudocysts contacting the stomach [18] because of its uncomplicated postoperative course $[19,20]$. During the last decade, the conventional open approach for drainage of pancreatic pseudocysts has given way to laparoscopyassisted pseudocystogastrostomy, a minimally invasive procedure with standardized stapler-performed anastomosis; this procedure, however, is not associated with Jurasz's name [21, 22].

Being an experienced surgeon, he shared knowledge about the etiology, pathology, and diagnosis of obscure internal disorders, irregular and atypical clinical pictures of characteristic symptoms and physical signs, and operative procedures, especially those employed to treat cysts. As one of the first Polish surgeons using an endoscope [23], spinal anesthesia for abdominal surgery [24, 25], and blood transfusion, Jurasz developed the Poznan surgical clinic into a consultation center for the chief surgeons of hospitals in western Poland [1] (Fig. 2). 


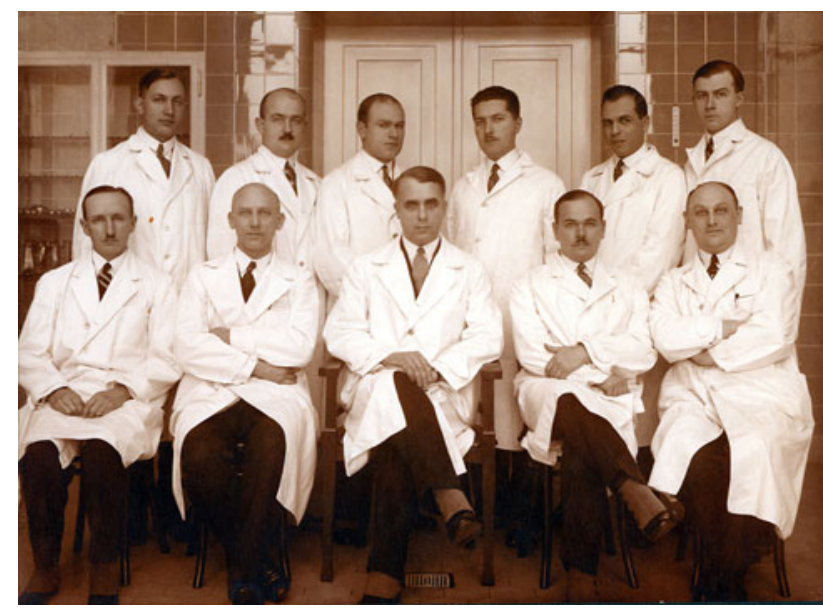

Fig. 2 Antoni Tomasz Jurasz (1882-1961) and his coworkers during the inter-war period. From left, in the lower line: Jan Krotoski, Jan Schlingmann, Antoni T. Jurasz, Feliks Skubiszewski, Czeslaw Maciejewski; in the upper line: Jozef Granatowicz, Tadeusz Suwalski, Stanislaw Winter, Ludwik Niczyperowicz, Ludwik Mierzejewski, Stanislaw Bylina). From Zapalski [6]

Jurasz acted with verve in many fields. He trained surgeons at home and abroad, including international training courses held in Germany. In 1927, he contributed to the foundation of the journal Chirurgia Kliniczna [Clinical Surgery], and 2 years later he started its English version, Chirurgia Clinica Polonica. In 1928, he was the cofounder and first president of the Society of Surgeons and Orthopedists of Western Poland. In 1935, invited by the Little Entente he went along with his assistants to Bucharest to perform demonstration operations in local hospitals [1]. A year later, invited by the Brazilian Academy of Medicine, he gave lectures and performed demonstration operations in Rio de Janeiro, San Paulo, and Curitiba. In 1937, he was the coauthor of the first original Polish textbook on surgery [26]. At the university he served as Dean of the Faculty of Medicine, Vice-President, and protector of student associations. He managed the activities of the Polish Red Cross in western Poland. He also made efforts to establish an AllSlavic Medical Society [1]. Thanks to him, the Polish language was recognized as one of the lecture languages during the 9th Congress of Société Internationale de Chirurgie (later, in addition, the International Society of Surgery) in Madrid in 1932, when he was National Delegate for Poland and President d'Honeur. As a distinguished medical man, he received many international honors, including Yugoslavian, Turkish, and Egyptian, and was elected honorary Fellow of medical and surgical societies in France, England, Brazil, and Panama [27].

The outbreak of World War II interrupted the rich scientific, professional, and social activities of Prof. Jurasz. Drafted into the army as a military surgeon at the end of August 1939, he took part in the defense of the fortress of
Modlin (situated in a fork of two rivers as a strategically important place to control a large territory around Warsaw, the capital of Poland). He helped hundreds of wounded servicemen during the 13-h bombardment. He was decorated for valor at the siege of the fortress of Modlin, which had to surrender in the face of a superior German force on September 29. Taken prisoner of war by the Germans, Jurasz managed to escape via Czechoslovakia and Hungary to France where he organized the Polish Red Cross. After France's capitulation in June 1940, he escaped with remnants of the Polish forces to England [28].

\section{In Scotland}

The remnant Polish Army was largely concentrated in Scotland, and some arrangements were made to train Polish medical officers in British military medicine. To overcome the language difficulty, the commander of the military hospital (in peacetime, a professor of genetics at the University of Edinburgh), Lt.-Col. Crew, put forward a proposal to organize a Polish Faculty of Medicine at the University of Edinburgh. The Polish military authorities and the exiled Polish government in London accepted this project enthusiastically and entrusted Prof. Jurasz to negotiate with the hierarchy of the university. Thanks to the Scots' friendliness and Jurasz's extraordinary competence and personal demeanor, a Polish School of Medicine was established and opened at at the University of Edinburgh on March 22, 1941. The establishment of a foreign medical school on British soil, with its own legal regulations, language, and authorities, was an unprecedented historical event [29].

Elected Dean, Prof. Jurasz soon began to organize a Polish hospital to provide medical care to Polish immigrants and give medical lessons to Polish students. Looking for financial support for the hospital, he left for the United States in 1942 and at American universities gave lectures on the Poles (who "were the first in Europe to take up arms and go forth into an unequal struggle"), Hitler's war on Polish culture and science, and the Polish School of Medicine in Edinburgh that preserved Polish scientific life. Jurasz's lectures moved his American audiences to increasing friendliness toward the Poles. During his stay in the United States, he also met with Mrs. Charlotte Kellogg, the President of the Paderewski Testimonial Fund in New York, which had been established to deliver humanitarian aid to poor Polish immigrants [29]. He convinced her that the best form of such assistance would be to purchase medical and other equipment for the Polish hospital in Edinburgh, and after the war it could be transferred to Poland. Because of the generosity of the Paderewski Fund, in 1943 included in the National War Fund in the United 
States, the Paderewski Hospital was named after the great pianist. The last major purchase made by the Paderewski Fund was a mobile hospital with 400 beds, kept in 23 automobiles [28].

The Paderewski Hospital was autonomous from the Polish School of Medicine. The teaching staff were represented at the hospital council by Prof. Jurasz, who was acting simultaneously as hospital superintendent and chief surgeon at the surgical ward. Closed in 1949, the Polish School of Medicine in Edinburgh had 228 graduates, among whom, contrary to first assumptions, only 19 returned to Poland. Others, fearing political reprisals from the Communist regime in Poland, decided to practice in England, Australia, France, Canada, Malaysia, New Zealand, Scotland, and the United States [27, 30].

\section{In the United States}

After the end of World War II, Jurasz visited the United States several times to confer with the Committee of the Paderewski Fund about details of the handover of the Paderewski Hospital equipment to Poland. During the summer of the following year, when closure of the Polish School of Medicine was inevitable, Jurasz and a delegation of the Paderewski Fund went to the Ministry of Health in Warsaw to hand over the mobile hospital and to coordinate delivery of the solid equipment from the Paderewski Hospital. Jurasz planned to hand over the equipment to a teaching hospital of the Medical University of Silesia in Katowice but with the prerequisites of suitable premises having been prepared and with supervision being entrusted to an American official. The visit was shortened because of a shocking incident: One of the delegates was arrested by the Secret Security Service.

Despite these unpleasant experiences, Jurasz went again to Poland in the autumn of 1947. It became apparent, though, that nothing had been done in Katowice to receive the permanent equipment from the Paderewski Hospital. Moreover, the Communist authorities did not agree to employ an American, and the mobile hospital that had been handed over the previous year had disappeared without anyone knowing what had happened to it. In Poznan, Jurasz was prevented from returning to the post he had held before the war, as he bitterly recorded in a letter to his family: "After the war, I was fired from the Faculty like a dog" [31].

Forced to return to Edinburgh, he emigrated to the United States that same year. He soon received American citizenship and permission to be engaged as a medical practitioner [32]. Feeling responsible for the 1200 packs containing equipment from the Paderewski Hospital that were stored in Newcastle, he offered them successively to the Polish community in England, the United States, and Canada but met with refusal to accept the gift because medical equipment and apparatus stored for several years was considered outdated and unsuitable for use. Finally, he sent an offer to the Puerto Rico Medical Association, with a vision of establishing a Paderewski Hospital Medical School there, but these negotiations also failed [33].

In 1948, the issue became a pretext to attack Jurasz in the press in Communist Poland. This outstanding surgeon was accused of appropriating the Paderewski Hospital equipment and selling it to Puerto Rico. The libel hurt Jurasz deeply. A few years later, when he worked as a surgical consultant at St. Clare's Hospital in New York he once again became the subject of a mendacious press campaign in Poland. This time, he was accused of selling the equipment to Israel. The Communist authorities provided the defamatory articles about Jurasz to Polish immigrants in London. Without verifying the information, the London Polish community magazines considered this transaction a scandal and joined the attack on Jurasz [34].

Living on the other side of the Iron Curtain, Jurasz could not defend himself in Poland. In letters to his family, secretly transferred to Poland, he explained: "With American money I was gradually buying instrumentation, diagnostic equipment, beds, X-rays, etc. in order to transfer the complete equipment to Poland after the war. Unfortunately, Poland was occupied [by Russians], and all of the plans came to nothing" [31].

The Communist press hunting for Jurasz, then living far away from Poland, raised the question of who was attacking him. It can be assumed that it was an action of the Secret Security Service aimed at Polish emigrants to set them against each other, thereby weakening the links with their compatriots in Poland. Attempts were made to undermine the moral authority and create a conflict between Jurasz and the Polish community in the United States as it supported political opposition in Poland. An aggressive campaign against Jurasz, during his last years practicing as a surgeon in Margaretville, left him with a feeling of deep regret and reluctance toward the Communist authorities in Poland [31].

He died of a heart attack on September 19, 1961 in New York City, shortly after returning from an International Conference of Surgeons in Dublin [32]. In addition to surgical procedures, his legacy was his own surgical school, whose representatives contributed to the development of surgery not only in Poland but also in Germany, England, the United States, Canada, New Zealand, Brazil, and other countries [30].

Conflict of interest None. 
Open Access This article is distributed under the terms of the Creative Commons Attribution Noncommercial License which permits any noncommercial use, distribution, and reproduction in any medium, provided the original author(s) and source are credited.

\section{References}

1. Drews R (1962) Prof. Antoni Jurasz. Pol Przegl Chir 34:193-198

2. Krehl L (1930) Pathologische Physiologie (Pathophysiology). F.C.W. Vogel, Leipzig

3. Jurasz AT (1911) Direkte Herzmassage bei Narkosenscheintod (Emergency direct cardiac massage under anaesthetic). Munchen Med Wochenschr 58:83

4. Jurasz AT (1914) Mobilisierung des Duodenum (Duodenal mobilization). Arch Klin Chir 104:118-167

5. Halas H (2003) Zarys historyczno-architektoniczny Szpitala Przemienienia Panskiego Zgromadzenia Siostr Milosierdzia sw. Wincentego a' Paulo do 1939 (A historical and architectural sketch of the Hospital of the Transfiguration of the Sisters of Charity of St. Vincent de Paul, to 1939). In: Szpital Przemienienia Panskiego 1823-2003 (The Hospital of the Transfiguration 1823-2003). Kontekst, Poznan, pp 50-51

6. Zapalski S (2003) 180 Lat działalności chirurgicznej w Szpitalu Klinicznym Nr 1 Przemienienia Panskiego w Poznaniu (180 Years of surgery at the Hospital of the Transfiguration, clinical hospital no. 1 in Poznań). In: Szpital Przemienienia Panskiego 1823-2003 (The Hospital of the Transfiguration 1823-2003). Kontekst, Poznan, pp 63-70

7. Jurasz AT (1929) Contribution on operative treatment of Graves disease. Chir Clin Pol 1:405

8. Jurasz AT (1928) Operacja wytwórcza pęcherza (Reconstructive bladder surgery). Pol Przegl Chir 7:453-454

9. Gupta NP, Kumar A, Sharma S (2008) Reconstructive bladder surgery in genitourinary tuberculosis. Indian J Urol 24:382-387

10. Jurasz AT (1931) Zur Frage der operative Behandlung der Pancreascysten. (On the surgical treatment of pancreatic cysts). Arch Klin Chir 164:272-279

11. Mossean LP, Kling S (1948) Pancreatic pseudocyst. Can Med Assoc J 59:550-554

12. Sawyer KC, Spencer JR, Lubchenco AE (1952) Proliferative cysts of the pancreas. Ann Surg 135:549-554

13. Warren WD, Marsh WH, Sandusky WR (1958) An appraisal of surgical procedures for pancreatic pseudocyst. Ann Surg 147:903-916

14. Jurasz AT (1928) Movable kidney. Proc R Soc Med 22:12-22

15. Jurasz AT (1937) Le traitement chirurgical des voies biliaires (Surgical treatment of the bile ducts). Arq Cir Clin Exp 1:13
16. Eliot E Jr (1936) Benign cicatricial structures of the bile ducts. Ann Surg 104:668-701

17. Jurasz AT (1921) Wrzod zolodka i dwunastnicy (Ulcers of the stomach and duodenum). Now Lek 33:89

18. Holeczy P, Danis J (1998) Laparoscopic transgastric pancreatic pseudocystogastrostomy: first experience with extraluminal approach. Hepatogastroenterology 45:2215-2218

19. Pirski MJ, Gacyk W, Zadrozny D et al (1997) Early and late evaluation of Jurasz's operations. Wiad Lek 50:130-134

20. Cucu A, Cornila R, Cristian A et al (2003) Pancreatic pseudocyst. Chirurgia Bucur 98:337-340

21. Fernández-Cruz L, Cesar-Borges G, López-Boado MA et al (2005) Minimally invasive surgery of the pancreas in progress. Langenbecks Arch Surg 390:342-354

22. Mori T, Abe N, Sugiyama M et al (2005) Laparoscopic pancreatic surgery. J Hepatobiliary Pancreat Surg 12:451-455

23. Jurasz AT (1913) Oesophagoskop oder Münzenfänger. (An oesophagoscope or a money trap?). Dtsch Med Wochenschr 39:2352

24. Jurasz AT (1914) Paravertebralanaesthesie im Dienste der Gallensteinchirurgie (Spinal anaesthesia in bile duct surgery). Zentrabl Chir 35:1409-1413

25. Jurasz AT (1926) O znieczuleniu rdzeniowym w operacjach brzusznych (Spinal anaesthesia in abdomen surgery). Pol Przegl Chir 5:47-53

26. Jurasz AT, Skubiszewski F (1937) Wątroba, trzustka, żołądek i dwunastnica. (Liver, pancreas, stomach, and duodenum). In: Wojciechowski A (ed) Podręcznik chirurgii (A textbook of surgery). Warszawska Ajencja Wydawnicza Delta, Warsaw, pp 327-542

27. Tomaszewski T (1981) Personal view. BMJ 283:669

28. Rostowski J (1955) History of the polish school of medicine. Gilmour \& Dean, Glasgow, p 46

29. Jurasz AT (1944) The Polish Medical School and the Paderewski Hospital, Edinburgh. In: Hill AV (ed) Polish Science and Learning. Oxford University Press, Oxford, pp 7-9

30. Rostowski J (1966) Polish school of medicine, University of Edinburgh 1941-49. BMJ 1:1349-1351

31. Jurasz AT (2011) Korespondencja 1945-1961 (Correspondence 1945-1961). Acta Medicorum Polonorum 1:117-128

32. Smith S (1961) A. T. A Jurasz, MD, Hon. F.R.S.C.-Obituary. BMJ 5257:966

33. Wionczek M (1948) Historia haniebna (A shameful story). Przekroj 180:5

34. Piotrowski M (1957) Za 75,000 dolarow sprzedano polski szpital. 7 Dni w Polsce (a Polish journal, edited in 1956-1965, now available in the Institute of National Remembrance in Warsaw) 24:5 